\title{
Digital competence and the use of technological resources by teachers in music conservatories and schools of music
}

\section{Competência digital e uso de recursos tecnológicos na área de ensino de conservatórios e escolas de música}

\author{
(iD) Isaac Diego García Fernández ${ }^{1}$ \\ Universidad Internacional de La Rioja (UNIR), Madrid, España \\ isaacdiego.garcia@unir.net \\ iD Juana María Anguita Acero² \\ Universidad de Castilla-La Mancha (UCLM), Ciudad Real, España \\ Juana.Anguita@uclm.es \\ Rosa de las Heras-Fernández $z^{3}$ \\ Universidad Internacional de La Rioja (UNIR), Madrid, España \\ rosa.heras@unir.net

\section{Diego Calderón-Garrido ${ }^{4}$} \\ Serra Húnter Fellow, Universitat de Barcelona (UB), Barcelona, España \\ dcalderon@ub.edu
}

\begin{abstract}
At present, digital technology provides innumerable new possibilities in the field of musical education. Its tools are, a valuable mediator in teaching-learning processes at the levels of elementary and university education, and specialisation. This study examines the knowledge and use of technological resources in the specific sphere of teaching in elementary, intermediate and superior stages
\end{abstract}

1 Isaac Diego García Fernández holds a PhD in Musicology and is a composer and sound artist. He has worked as a professor at the European University of Madrid. Also, he has been a visiting researcher at The City University of New York and is currently a professor-researcher at the International University of La Rioja.

2 Juana María Anguita Acero holds a PhD in Educational Sciences. She has worked as an in-house translator for Lionbridge and for the International Baccalaureate. She has also collaborated with and worked for several universities. At the present time, she is a professor and researcher at the University of Castilla-La Mancha.

3 Rosa de las Heras-Fernández holds a PhD in Music and Dance (Rey Juan Carlos University). She got an Extraordinary Doctorate Award. She is the Coordinator and PI (Principal Investigator) of the Music Area at the International University of La Rioja.

4 Diego Calderón-Garrido holds a PhD in Educational Technology and a PhD in History of Art. He is Serra Húnter Fellow at the University of Barcelona, Faculty of Education. 
in music conservatories and schools of music. By means of an online questionnaire administered to 82 teachers in this field, significant data was obtained regarding said knowledge and use of technological tools. These results provide evidence that those tools are scarcely applied, whether in preparing classes or in learning processes in the classroom. The only positive data appears in connection with the use of sound and sheet music editors.

Palavras-chave: Digital Technology. Musical Education. Music Conservatories. Schools of Music.

Resumo:Hoje, atecnologia digital trazumuniverso denovas possibilidades no campo da educação musical. Suas ferramentas se mostram como um valioso mediador nos processos de ensino-aprendizagem, seja na educação básica, universitária ou especializada. Este estudo examina o conhecimento e a utilização de recursos tecnológicos na área específica do ensino em conservatórios --fundamental, médio e superior- e escolas de música. Através de um questionário online dirigido a 82 professores da área, foram obtidos dados significativos em relação ao conhecimento e utilização de ferramentas tecnológicas. Esses resultados mostram sua escassa aplicação, tanto na preparação das aulas, quanto nos processos de aprendizagem desenvolvidos em sala de aula. Apenas dados positivos podem ser vistos no uso de editores de som e de partitura.

Keywords: Tecnologia Digital. Educação Musical. Conservatórios de Música. Escolas de Música.

Submetido em: 31 de maio de 2021

Aceito em: 25 de setembro de 2021 
Digital competence and the use of technological resources by teachers in music...

Isaac Diego García Fernández • Juana María Anguita Acero • Rosa de las Heras-Fernández •

Diego Calderón-Garrido

\section{Introduction: musical education and new technologies}

The permanent development of information and communication technologies may be a decisive factor in the profound transformations that are taking place in all sectors of contemporary society. In the educational context, their impact has led to a growing interest in the field of teaching and in multiples areas of research. In the last ten years, new technologies have acquired greater relevance and are attracting greater attention (Adelsberger, Collis and Pawlowski, 2013). According to Webster (2002: 38), "Music is everywhere in these media, and music teachers are continually inspired to use these computer-based technologies in their work. [...] Thus, our fascination with technology and its role in teaching and learning continues to grow". From this perspective, it is essential for teachers to stay abreast of technological innovations in order to use them efficiently for teaching and to satisfy the needs of new generations (Gorgoretti, 2019). As pointed out by Román-Álvarez (2017: 481), "whether we like it or not, technologies are part of our daily life. Learning to coexist with them is not only an obligation, but also a need in order to avoid falling into a new type of illiteracy, namely technological". ${ }^{5}$ However, the use of ICTS in the classroom does not guarantee a competent pedagogical approach (Krumsvik, 2008: 279). In this sense, Gisbert, González and Esteve (2016: 78) advocate for taking another step in teacher training, which is traditionally separated from the area of study and pedagogical reflection, and continues to be generic, technical or excessively geared at elementary alphabetization.

The constant technological advance has produced a wide range of resources that can be used in educational contexts; but it has also provoked changes in teaching methods and the profile and role of teachers, currently seen as facilitators of learning (Ho, 2004: 57). This aspect reveals that we are facing a process of transformation that is more complex and deeper than what could be initially

5 Original text: “Las tecnologías, queramos o no forman parte de nuestra vida cotidiana. Aprender a convivir con ellas no solo es una obligación, sino una necesidad para no caer en un nuevo analfabetismo: el tecnológico". 
Digital competence and the use of technological resources by teachers in music...

Isaac Diego García Fernández • Juana María Anguita Acero • Rosa de las Heras-Fernández • Diego Calderón-Garrido

suspected. As highlighted by Delalande (2004, p. 19), technologies are not only tools, but also the effect of a paradigm that promotes another model of musical society. Delalande (2004) establishes two major «technological revolutions» in the history of western classical music. The first one is the development of musical writing, which during the Middle Ages ceased to be a simple means of conservation and transmission and became a way of composing polyphonic music. From this perspective, musical writing must be construed as a compositional tool, as a technology that enables developing sound structures that are unimaginable from the standpoint of orality (GARCÍA, 2020). The second revolution occurred in the 20th century with the possibility of recording and reproducing sounds, and the subsequent development of electroacoustic and computer resources. Delalande (2004) establishes a clear correspondence between the two technological landmarks (musical writing and the phonograph), as both produced profound consequences in the manner of thinking music at the aesthetic and creative level as well as the social and pedagogical one. As stated by Mark and Madura (2010: 140), "technology will continue to evolve and music teachers will need to be prepared for a shifting paradigm for music education". Nonetheless, comprehension of musical technology, which is mainly acknowledged as a tool, is still limited (Southcott and Crawford, 2011: 122). This justifies the need to promote changes that have greater structural repercussion. For example, Gorgoretti $(2019$, p. 1) insists on the importance of updating curriculums to integrate ICTs in the training of music teachers. This also depends on two major factors, namely the economic investment to equip schools and their classrooms, and the training of teachers (RománÁlvarez, 2017: 482). As Aróstegui points out (2010: 18):

The educational possibilities of Information and Communication Technologies (ICT) and the need to teach students how to use them are two major challenges faced by the school system. In order to deal with these new challenges successfully, it is necessary to provide schools with materials which will also have to be constantly updated as this technology advances, in addition to proper training 
Digital competence and the use of technological resources by teachers in music...

Isaac Diego García Fernández • Juana María Anguita Acero • Rosa de las Heras-Fernández • Diego Calderón-Garrido

for teachers - not only in technical terms, but also in terms of the educational use of these resources.

In this process of constant teacher adaptation, one must also bear in mind that in Spain, the country in which this study was carried out, and in the majority of western countries, students have normally been alphabetized in digital environments (Hagood and Skinner, 2012: 4), both in respect to the use of mobile devices with tactile screens (PDAs, iPods, iPads, tablets and smartphones) and the use of multiple applications that enable them to play with sounds and music in a direct and intuitive manner (Stephenson and Limbrick, 2015: 3777). These resources could be a medium with which to foment creativity in connection with strategies such as the resolution of problems. Jeffrey and Craft (2004, p. 84) consider that one of the principal characteristics of creativity is 'possibility thinking', as it enables students who engage in activities based on new technologies to take control and act in an innovative manner. In order to implement these strategies in an effective manner in the field of musical education, Webster (2007, p. 1311-1328) proposes three necessary conditions: a) appropriate technological development; b) availability and integration; and c) to always follow a constructivist approach in teaching-learning processes. In addition, teaching critical comprehension of the tools that are being used is also essential, given that as Aróstegui (2010: 28) points out, "knowledge is a social construction. This is an ideological question, which is frequently denied if it is stated that this resource is objective and aseptic in itself". From a similar perspective, Román-Álvarez (2017, p. 483) proposes the example of Web 2.0 (or online) resources and free or open source software, which allow creating and freely sharing, without the need for a large economic investment (by schools or students). Moreover, this promotes education in values and respect for community work, as evidenced by the use of free musical applications such as Audacity and Musescore. 
Digital competence and the use of technological resources by teachers in music... Isaac Diego García Fernández • Juana María Anguita Acero • Rosa de las Heras-Fernández • Diego Calderón-Garrido

\section{Digital competence in the field of teaching in music con- servatories and schools of music}

In respect to other educational spheres, the specific context of teaching in music conservatories and schools of music shows greater resistance to incorporating pedagogical innovations related to the new technologies (Díez-LATORRE, 2018). In his study on the integration of ICTs in conservatories of music in the Spanish region of Galicia, Belló (2012) found that the use of educational technologies was scarce, due to a low level of motivation, as well as lack of time and training of teachers. Along the same lines, Palau, Usart and Ucar (2019: 24) state that "in general, in conservatories of music there is very little use of educational technologies, with teachers claiming lack of time and training in this field. In addition, few scientific studies have been devoted to measuring and analyzing teacher self-perception of their own Digital Competence".6 Authors such as Gutiérrez, Palacios and Torrego (2010, p. 269) argue that in order to achieve the adequate integration of ITCs in the curriculums, it is essential to focus on the initial training phase of future teachers. In contrast, Díez-Latorre and Carrera $(2018$, p. 41) uphold that the necessary preparation to exercise future teaching effectively must be acquired in the elementary and professional conservatories and schools of music, where the content of curriculums and teaching guidelines of the subject of Musical Pedagogy must be urgently revised. In addition, this would also entail adopting a more reflexive and critical approach in respect to the pedagogical processes, since not only is it a question of acquiring aptitudes and knowledge, but also of seriously reconsider the implications that ICTs may have in their future profession (Díez-Latorre, 2018: 32). Lastly, in addition to the aforementioned initial training and preparation in superior music conservatories, Bautista and Fernández-Morante (2018, p. 4) state that another fundamental element of this technological implementation is academic research promoted by universities.

\footnotetext{
6 Original text: En los conservatorios de música en general existe un parco uso de la tecnología educativa, con un profesorado que alega falta de tiempo y formación en este ámbito. Además, pocos son los estudios científicos dedicados a medir y estudiar la autopercepción de los docentes sobre su propia Competencia Digital".
} 
Digital competence and the use of technological resources by teachers in music...

Isaac Diego García Fernández - Juana María Anguita Acero • Rosa de las Heras-Fernández • Diego Calderón-Garrido

On the other hand, note should be made that new technologies in themselves do not entail pedagogical innovation. Their effectiveness depends on their use and teachers' attitudes. In this sense, different studies show very positive results in the use of new technologies, particularly in common subjects. For example, note should be made of the contributions of ICTs in the field of auditory education, particularly of activities involving dictation, listening and transcription of musical fragments (Balo, Lago and Ponce de León, 2014). Another area that provides interesting solutions is the application of specific software, such as applications for audio, sheet music editors, accompaniment software, virtual classrooms, etc. (López, 2011). In the specific case of sheet music editors, their effectiveness to improve sight-singing has been confirmed (Galera, Tejada and Trigo, 2013), as well as auditory training and the acquisition of rhythmic abilities (Ordoñana, Laucirica and Tejada, 2004). Mention should also be made of the benefits of using digital boards in elementary and professional conservatory classrooms, in particular for the subject of Musical Language (Bernabé, 2013).

However, it is evident that a traditional pedagogical model based on a direct teacher-student relationship continues to predominate in instrumental music instruction in conservatories and schools of music in Spain. As highlighted by Bautista and Fernández-Morante (2018, p. 4), in this 'conservatory model', the maestro is sometimes presented as a prominent figure (more artist than teacher) whose methods are not usually supervised or questioned. From this point of view, "the new teaching methodologies constitute a threat to the individualism that prevails in the instrumental pedagogical tradition, in a competitive system in which talent takes precedence" (Bautista and Fernández-Morante, 2018: 4).7 This aspect has been even more clearly evidenced since the 2020 global health crisis caused by COVID-19, in which confinement has required finding alternatives for instrumental music instruction. Palau, Mogas and Ucar (2020) point out that the closing of schools during the pandemic, with the resulting physical separation of students and

7 Original text: “las nuevas metodologías de enseñanza constituyen una amenaza al individualismo imperante en la tradición pedagógica instrumental, dentro de un competitivo sistema en el que prima el talento". 
Digital competence and the use of technological resources by teachers in music...

Isaac Diego García Fernández - Juana María Anguita Acero • Rosa de las Heras-Fernández • Diego Calderón-Garrido

teachers, has highlighted the need to consider remote teaching models in which technological resources can provide important solutions. Nonetheless, the difficulties to virtualize instrumental music subjects also revealed that many teachers are not convinced by a possible change of the teaching model, and that the majority are reluctant to modify their traditional in-person model (Palau, Mogas and Ucar, 2020: 108). As indicated by Crawford et al. (2020), transformation of traditional or mixed learning to a completely virtual teaching system requires time. In order to implement an online model for instrumental music instruction, Bates (2020) suggests establishing several strategies, such as providing support with prior professional advice, obtaining appropriate technological tools, structural organisation, adjusting student's workload, avoiding group conferences, adapting to available resources, etc. Hence this paper aims to determine the digital competence and use of technology of music conservatory and music school teachers.

\section{Methodology}

To achieve this objective, a study was carried out based on an exploratory, correlational and transversal descriptive survey (Bisquerra, 2004) through the application of an online ad hoc questionnaire. The choice of an online questionnaire was due to the impossibility of having face to face contact with teachers due to the restrictions imposed as a result of COVID-19. However, this entailed a certain amount of subjectivity, as the results were based on the teachers surveyed.

The questionnaire used was the Questionnaire of Digital Teaching Competences and Use of Digital Technology in the University Music Classroom (available at https://reunir.unir.net/ handle/123456789/6965) designed and validated by CalderónGarrido, Carrera y Gustems-Carncier (2020). This is a self-report to evaluate the knowledge and use of different technological resources. The questionnaire was designed on the basis of the 
Digital competence and the use of technological resources by teachers in music...

Isaac Diego García Fernández • Juana María Anguita Acero • Rosa de las Heras-Fernández • Diego Calderón-Garrido

opinion of 16 experts. The validation first consisted of an analysis to verify the Kayser, Meyer and Olkin (KMO) adequacy measure and the Bartlett test, which showed its adequacy (KMO $=.812 ; \mathrm{X} 2$ $=3176.936 ; p<.001)$. The exploratory factor analysis showed the adequacy of the eight dimensions presented, indicating the weight of the 8 factors proposed and explaining a total of $75.838 \%$ of the variation. This questionnaire showed excellent internal consistency $(a=0.945)$.

Although the sample analyzed in this study differs from the one to which the original questionnaire was geared, the dimensions analyzed are common to both university music professors and the ones at conservatories and schools of music. In this sense, the sample analyzed in this study also showed excellent internal consistency, $(a=0.943)$, replicating the adequacy $(\mathrm{KMO}=.798 ; \mathrm{X} 2$ $=2918.936 ; p<.001)$ and the 8 factors proposed.

After discarding the answers that had not been fully completed, the valid sample consisted of 82 participants from 47 different educational centres in Spain, of which $43.9 \%$ were women and $56.1 \%$ were men. Their average age was 40.11 (SD = 9.657). In respect to the type of subjects they taught, $64.6 \%$ were instrumental, $23.2 \%$ theoretical and $12.2 \%$ both. In respect to the educational level or main work centre, $48.8 \%$ worked in an intermediate conservatory, $22 \%$ in an elementary conservatory, $14.6 \%$ in a superior conservatory, and another $14.6 \%$ in a School of Music.

The programme used for the computing and statistical analysis of the results was version 21.0 of IBM Statistic Package for Social Science (SPSS). A minimum confidence interval of 95\% was established in all cases. The statistics used were those of MannWhitney and of Kruskal-Wallis, first performing the normality tests of the Kolmogorov-Smirnov or Shapiro-Wilk sample, depending on the needs, as well as Levene's test to verify the homogeneity of variance. Version 1.5.2 of ATLAS.Ti was used for the qualitative analysis of the answers. 
Digital competence and the use of technological resources by teachers in music...

Isaac Diego García Fernández • Juana María Anguita Acero • Rosa de las Heras-Fernández • Diego Calderón-Garrido

\section{Results}

In the case of tools geared at auditory education, the development of audiovisuals, sequencers, software to learn how to handle musical instruments and software for the development of vocal capacities, the data revealed almost complete non-existence of knowledge and use in preparing classes and in the classroom and teaching. There was a little more knowledge and use of sound and sheet music editors. Table 1 shows all of the data obtained.

Table 1. Answers depending on the different tools

\begin{tabular}{|c|c|c|c|c|c|}
\hline & & $\begin{array}{l}\text { NULL/ } \\
\text { NEVER }\end{array}$ & $\begin{array}{l}\text { SUPERFICIAL/ } \\
\text { A FEW TIMES }\end{array}$ & $\begin{array}{l}\text { AMPLE/ } \\
\text { OFTEN }\end{array}$ & $\begin{array}{c}\text { DEEPI } \\
\text { ALWAYS }\end{array}$ \\
\hline \multirow{4}{*}{$\begin{array}{l}\text { AUDITORY } \\
\text { EDUCATION }\end{array}$} & KNOWLEDGE & $33(40.2 \%)$ & $35(42.7 \%)$ & $10(12.2 \%)$ & $4(4.9 \%)$ \\
\hline & CLASS PREPARATION & $55(67.1 \%)$ & $22(26.8 \%)$ & $3(26.8 \%)$ & $2(2.4 \%)$ \\
\hline & USE IN CLASSROOM & $61(74.4 \%)$ & $15(18.3 \%)$ & $4(4.9 \%)$ & $2(2.4 \%)$ \\
\hline & TEACHING & $63(73.2 \%)$ & $16(19.5 \%)$ & $4(4.9 \%)$ & $2(2.4 \%)$ \\
\hline \multirow{4}{*}{ AUDIOVISUALS } & KNOWLEDGE & $19(23.2 \%)$ & $35(42.7 \%)$ & $23(28 \%)$ & $5(6.1 \%)$ \\
\hline & CLASS PREPARATION & 37 (45.1\%) & $31(37.8 \%)$ & $14(17.1 \%)$ & 0 \\
\hline & USE IN CLASSROOM & $42(51.2 \%)$ & 32 (39\%) & $7(8.5 \%)$ & $1(1.2 \%)$ \\
\hline & TEACHING & $56(68.3 \%)$ & $20(24.4 \%)$ & $5(6.1 \%)$ & $1(1.2 \%)$ \\
\hline \multirow{4}{*}{$\begin{array}{l}\text { AUDIO } \\
\text { EDITORS }\end{array}$} & KNOWLEDGE & $9(11 \%)$ & 35 (42.7\%) & $26(31.7 \%)$ & $12(14.6 \%)$ \\
\hline & CLASS PREPARATION & $23(28 \%)$ & $38(46.3 \%)$ & $19(23.2 \%)$ & $2(2.4 \%)$ \\
\hline & USE IN CLASSROOM & $33(40.2 \%)$ & $29(35.4 \%)$ & $19(23.2 \%)$ & $1(1.2 \%)$ \\
\hline & TEACHING & $40(46.8 \%)$ & $30(36.6 \%)$ & $11(13.4 \%)$ & $1(1.2 \%)$ \\
\hline \multirow{4}{*}{$\begin{array}{l}\text { SHEETMUSIC } \\
\text { EDITORS }\end{array}$} & KNOWLEDGE & $2(2.4 \%)$ & $17(20.7 \%)$ & $35(42.7 \%)$ & $28(34.1 \%)$ \\
\hline & CLASS PREPARATION & $7(8.5 \%)$ & $25(30.5 \%)$ & 32 (39\%) & $18(22 \%)$ \\
\hline & USE IN CLASSROOM & $21(25.6 \%)$ & $23(28 \%)$ & $25(30.5 \%)$ & $13(15.9 \%)$ \\
\hline & TEACHING & 27 (32.9\%) & $30(36.6 \%)$ & $16(19.5 \%)$ & $9(11 \%)$ \\
\hline \multirow{4}{*}{$\begin{array}{l}\text { SOUND } \\
\text { GENERATORS }\end{array}$} & KNOWLEDGE & $28(34.1 \%)$ & $27(32.9 \%)$ & $18(22 \%)$ & $9(11 \%)$ \\
\hline & CLASS PREPARATION & $42(51.2 \%)$ & $23(28 \%)$ & $14(17.1 \%)$ & $3(3.7 \%)$ \\
\hline & USE IN CLASSROOM & 47 (57.3\%) & $17(20.7 \%)$ & $13(15.9 \%)$ & $5(6.1 \%)$ \\
\hline & TEACHING & $53(64.6 \%)$ & $19(23.2 \%)$ & $8(9.8 \%)$ & $2(2.4 \%)$ \\
\hline \multirow{4}{*}{ SEQUENCERS } & KNOWLEDGE & 35 (42.7\%) & $22(26.8 \%)$ & $14(17.1 \%)$ & $11(13.4 \%)$ \\
\hline & CLASS PREPARATION & $55(67.1 \%)$ & $14(17.1 \%)$ & $10(12.2 \%)$ & $3(3.7 \%)$ \\
\hline & USE IN CLASSROOM & $55(67.1 \%)$ & $15(18.3 \%)$ & $9(11 \%)$ & $3(3.7 \%)$ \\
\hline & TEACHING & $60(73.2 \%)$ & $12(14.6 \%)$ & $8(9.8 \%)$ & $2(2.4 \%)$ \\
\hline
\end{tabular}


Digital competence and the use of technological resources by teachers in music... Isaac Diego García Fernández • Juana María Anguita Acero • Rosa de las Heras-Fernández • Diego Calderón-Garrido

\begin{tabular}{llcccc}
\hline & KNOWLEDGE & $49(59.8 \%)$ & $24(29.3 \%)$ & $7(8.5 \%)$ & $2(2.4 \%)$ \\
INSTRUMENT & CLASS PREPARATION & $69(84.1 \%)$ & $9(11 \%)$ & $2(2.4 \%)$ & $2(2.4 \%)$ \\
SOFTWARE & USE IN CLASSROOM & $69(84.1 \%)$ & $7(8.5 \%)$ & $4(4.9 \%)$ & $2(2.4 \%)$ \\
& TEACHING & $68(82.9 \%)$ & $8(9.8 \%)$ & $4(4.9 \%)$ & $2(2.4 \%)$ \\
\hline \multirow{2}{*}{ VOCAL } & KNOWLEDGE & $59(72 \%)$ & $17(20.7 \%)$ & $5(6.1 \%)$ & $1(1.2 \%)$ \\
SOFTWARE & CLASS PREPARATION & $69(84.1 \%)$ & $10(12.2 \%)$ & $3(3.7 \%)$ & 0 \\
& USE IN CLASSROOM & $71(86.6 \%)$ & $6(7.3 \%)$ & $5(6.1 \%)$ & 0 \\
& TEACHING & $73(89 \%)$ & $4(4.9 \%)$ & $5(6.1 \%)$ & 0 \\
\hline
\end{tabular}

Depending on gender, statistical differences are observed in the case of knowledge of audio editors $(z=550.5 ; p=.006)$, knowledge of sequencers ( $z=585.0 ; p=.003)$ and knowledge of software geared at developing vocal competences $(z=636.0 ; p=$ .023). In all cases men scored higher than women. However, this does not mean that there is a difference depending on gender in the general knowledge of digital resources for musical education $(z=626.5 ; p=.059)$.

The sole correlation reported in respect to the age of participants is one between the latter and knowledge of sequencers $(r=.221 ; p$ $=.046)$, and use of sequencers $(r=.261 ; p=.018)$.

In no cases were differences detected depending on the type of instruction (instrumental, theoretical or both).

Differences were reported depending on the level of education in the case of audio editor instruction $(X 23=12.982 ; p=.005)$ and of sheet music editors $(X 23=9.576 ; p=.023)$, and also in the use $(X 23=8.689 ; p=.034)$ and instruction $(X 23=8.085 ; p=.044)$ of vocal software. The difference was with the teachers of the superior conservatory, who scored higher in all cases.

It was found that in all cases knowledge of a resource correlated directly with its use in preparing classes and its use in the classroom. Although this may seem obvious, it is highlighted due to its use in the discussion, given the feedback it entails. Said correlations are shown in Table 2. 
Digital competence and the use of technological resources by teachers in music... Isaac Diego García Fernández • Juana María Anguita Acero • Rosa de las Heras-Fernández • Diego Calderón-Garrido

Table 2. Correlations between knowledge of a resource and the other parameters

\begin{tabular}{llll}
\hline & PREPARATION & USE & INSTRUCTION \\
\hline $\begin{array}{l}\text { KNOWLEDGE OF AUDI- } \\
\text { TORY EDUCATION }\end{array}$ & $R=.676 ; P<.001$ & $R=.628 ; P<.001$ & $R=.651 ; P<.001$ \\
$\begin{array}{l}\text { KNOWLEDGE OF AU- } \\
\text { DIO-VISUALS }\end{array}$ & $R=.561 ; P<.001$ & $R=.609 ; P<.001$ & $R=.355 ; P=.001$ \\
$\begin{array}{l}\text { KNOWLEDGE OF AUDIO } \\
\text { EDITORS }\end{array}$ & $R=.237 ; P<.001$ & $R=.447 ; P<.001$ & $R=.289 ; P=.009$ \\
$\begin{array}{l}\text { KNOWLEDGE OF SHEET } \\
\text { MUSIC EDITORS }\end{array}$ & $R=.662 ; P<.001$ & $R=.525 ; P<.001$ & $R=.396 ; P<.001$ \\
$\begin{array}{l}\text { KNOWLEDGE OF SOUND } \\
\text { GENERATORS }\end{array}$ & $R=.734 ; P<.001$ & $R=.519 ; P<.001$ & $R=.574 ; P<.001$ \\
$\begin{array}{l}\text { KNOWLEDGE OF SE- } \\
\text { QUENCERS }\end{array}$ & $R=.766 ; P<.001$ & $R=.710 ; P<.001$ & $R=.743 ; P<.001$ \\
$\begin{array}{l}\text { KNOWLEDGE OF INSTRU- } \\
\text { MENT SOFTWARE }\end{array}$ & $R=.605 ; P<.001$ & $R=.633 ; P<.001$ & $R=.665 ; P<.001$ \\
$\begin{array}{l}\text { KNOWLEDGE OF VOCAL } \\
\text { SOFTWARE }\end{array}$ & $R=.706 ; P<.001$ & $R=.676 ; P<.001$ & $R=.613 ; P<.001$ \\
\hline
\end{tabular}

In this sense, the cluster analysis showed similarities between knowledge, use in preparation, use in classes and software instruction geared at developing instrumental competences. However, as mentioned earlier, said teachers were only a small part of the total sample.

In respect to problems faced by teachers in implementing the digital technology in their teaching, $63.4 \%$ considered that they had problems. These answers were analysed with the Atlas.ti software and grouped in four major areas. The first and most common was the generalized complaint about the centre's lack of resources ( $n$ = 34). A problem of lack of training of teachers was also detected $(n=21)$. The analysis revealed concerns regarding students' lack of resources $(n=12)$. Finally, in some cases existing problems were also associated to the lack of time, as the use of digital technologies was not included in the curriculum $(n=9)$.

In respect to training in the use of digital technology, in most cases ( $n=46)$ mention was made of self-training, accompanied in some cases by courses organised by the different administrations 
Digital competence and the use of technological resources by teachers in music...

Isaac Diego García Fernández • Juana María Anguita Acero • Rosa de las Heras-Fernández • Diego Calderón-Garrido

$(n=23)$. Seven answers referred exclusively to prior training. The others $(n=6)$ made no comments regarding prior training.

\section{Discussion and conclusions}

The survey administered to teachers of music conservatories and municipal schools of music has shed light on the technological and digital competences of a specific sector of music teachers in two different environments, namely those of formal and nonformal music education (BERMEL and DIAZ, 2014), which, however, could share their feedback and combine their teaching and learning strategies (ARRIAGA SANZ, ALBA-EGUÍLUZ and CABEDOMAS, 2019).

In Spain, the country in which the study was carried out, the teachers in these centres provide instruction to students who, in general terms, are digitally literate and for whom the use of technology is present on a daily basis (CALDERÓN-GARRIDO, CARRERA, and GUSTEMS-CARNICER, 2021). Hence, teachers must take this into account and acknowledge that applying ICTs in their teaching work allows them to interpret and organise new types of learning (MAÑAS and ROIG-VILA, 2019) and to encourage the development of creativity (STEPHENSON and LIMBRICK, 2015; GIRÁLDEZ, 2015). However, the results show that music teachers in these contexts have not used sufficient technological tools in the classroom. The musical educational tools used most are sound editors (SILVEIRA and GAVIN, 2016) and sheet music editors. The latter are used in learning musical language, to compose, to listen, etc. (BELLINI, 2008; BRODSKY et al., 2008; LETAILLEUR, BISESI and LEGRAIN, 2020; PODOLAK and SCHMUCKLER, 2019; WÖLLNER et al., 2003), particularly amongst teachers of superior musical education. These results coincide with studies that point out how teachers of superior music education make better use of digital tools and how technology acquires greater prominence at that level (CALDERÓN-GARRIDO, CISNEROS, GARCÍA, and DE LAS HERAS, 
Digital competence and the use of technological resources by teachers in music...

Isaac Diego García Fernández • Juana María Anguita Acero • Rosa de las Heras-Fernández • Diego Calderón-Garrido

2019). However, as mentioned earlier, there are other technological tools for the development of musical competences that are hardly used by teachers. These are related to auditory development, sequencers, software to learn how to handle musical instruments and software for the development of vocal capacities. In respect to auditory development, the use of practice software is proposed (CHAN et al., 2006), along with the use of sequencers and sound generators (FARRIMOND et al., 2011), as well as auxiliary software for instrumental performance (NIJS and LEMAN, 2014; ROWE et al., 2015) and for the development of vocal capacities (REID et al., 2017).

The study reveals some of the reasons which may explain why teachers of superior music conservatories and schools of music do not integrate musical technologies into their classes. Four basic scenarios have been classified: on one hand, the lack of resources in the centres. The National Association of Schools of Music highlights a similar characteristic as one of the drawbacks to integrating technologies in teacher training syllabuses (BAUER and DAMMERS, 2016). In addition, the evidence points to the need to train teachers in technological tools. This coincides with other studies that reveal a need for permanent training for music teachers (FERM THORGSEN et al., 2016) as well as self-education, indicating that there are significant deficiencies that must be considered in the field of educational technology in connection with superior musical education (CALDERÓN-GARRIDO, CISNEROS, GARCÍA, and DE LAS HERAS, 2019) and in non-formal music education (BERMEL and DIAZ, 2014). On the other hand, and with respect to students' possible lack, it is important to recall that there are different cell phone applications that are free, are quite widespread amongst students and do not require any specific classroom tool ( $\mathrm{CHO}$ et al., 2019). Furthermore, free high-profile platforms used in related areas such as dance can be useful to create deposits that facilitate learning throughout a student's life (HUDDY, 2017). This free software includes Audacity to edit audio and Musescore to edit sheet music (CALDERÓN-GARRIDO, GUSTEMS-CARNICER and 
Digital competence and the use of technological resources by teachers in music...

Isaac Diego García Fernández • Juana María Anguita Acero • Rosa de las Heras-Fernández • Diego Calderón-Garrido

CARRERA, 2020). Lastly, the participants of this study point to the lack of time of teachers as an obstacle for the use of technology in the classroom, given that it is not included in the curriculum. As a solution to this stumbling block, in the United States there is a proposal to implement a comprehensive technology syllabus in related areas of study, such as the degree in dance (RISNER and ANDERSON, 2008).

On the basis of the data provided by this study, it can be concluded that there continues to exist considerable resistance to incorporating pedagogical innovations related to the new technologies in music conservatories and municipal schools of music. It should be noted that at present implementation of ICTS in society in general is increasing exponentially, and the same applies to this specific area of education. Moreover, this fact has been evidenced since the onset of the global COVID-19 health crisis, during which confinements have made it necessary to reconsider the traditional in-person teaching models based on the teacher-student relationship. This has led to substantial changes in teaching worldwide (DWIVEDI, et al., 2020). Finally, this health situation has revealed the changes that are occurring in the field of musical pedagogy and teaching, in which it is clear that ICTs will play a fundamental role in the years to come.

The limitations of this study are also an indication of future work. On the one hand, we believe it is essential to determine whether the results obtained here are related to teachers' professional experience. In addition, determining if the results are similar in all instrumental specialties would provide a deeper understanding of the work carried out by each teacher. On the other hand, extending the sample not only in Spain but to other countries and cultural environments would also be of great interest. 
Digital competence and the use of technological resources by teachers in music... Isaac Diego García Fernández • Juana María Anguita Acero • Rosa de las Heras-Fernández • Diego Calderón-Garrido

\section{References}

ADELSBERGER, HEIMO H.; COLLIS, BETTY; PAWLOWSKI, JAN MARTIN. (EDS.). HANDBOOK ON INFORMATION TECHNOLOGIES FOR EDUCATION AND TRAINING. BERLIN: SPRINGER-VERLAG, 2013, 493P.

Aróstegui, Jose Luis. Risks and promises of ICT (information and communication technologies) for music education. Hellenic Journal of Music, Education and Culture, v. 1, n. 1, p. 17-31, 2010.

ARRIAGA SANZ, Cristina; DE-ALBA-EGUÍLUZ: Balkune, CABEDO-MAS, Alberto. La importancia de la colaboración entre profesorado de música de diferentes entornos. Un estudio de caso en el ámbito formal y no formal. Revista Música Hodie, v.19, p. 1-16, 2019.

Balo, Mónica.; Lago, Pilar; Ponce de León, Luis. Los alumnos ante el dictado musical. Las TIC como aliadas para mejorar las experiencias. Didáctica, Innovación y Multimedia (DIM), n. 28, p. 1-14, 2014. Bates, Tony. Advice to those about to teach online because of the corona-virus. Online Learning and Distances Education Resources. 2020. Available at: https://www.tonybates.ca/2020/03/09/advice-tothose-about-to-teach-online-because-of-the-corona-virus/ Accessed on May 1, 2021.

BAUER, William; DAMMERS, Richard. Technology in music teacher education: A national survey. Research. Perspectives in Music Education, v. 18, n. 1, p. 2-15, 2016. Available at: https://www. ingentaconnect.com/content/fmea/rpme/2016/00000018/00000001/ art00001 Accessed on May 1, 2021.

Bautista, Alfredo; Fernández-Morante, Basilio. Monográfico sobre Investigación en Interpretación Musical: Implicaciones para el Desarrollo Profesional Docente. Psychology, Society, \& Education, v. 1, n. 10, p. 1-13, 2018. DOI: http://dx.doi.org/10.25115/psye.v10i1.1869 Belló, José María. Las tecnologías de la Información y Comunicación en los conservatorios de Música de Galicia: análisis de los usos, actitudes y formación del profesorado. Doctoral Thesis. Universidad de A Coruña, 2012, 734p. 
Digital competence and the use of technological resources by teachers in music... Isaac Diego García Fernández • Juana María Anguita Acero • Rosa de las Heras-Fernández • Diego Calderón-Garrido

BELLINI, PierFrancesco. XML music notation modelling for multimedia: MPEG-SMR. In K. Ng y P. Nesi (Eds.), Multimedia technologies:

Concepts, methodologies, tools, and applications IGI Global, 2008. p. 1683-1706. DOI: https://doi.org/10.4018/978-1-59904-150-6.ch003

Bernabé, Mar. Enseñanzas de Régimen Especial y nuevas tecnologías. Una experiencia en el Conservatorio Profesional de Música de Torrente. Educatio Siglo XXI, v. 1, n. 31, p. 192-212, 2013.

BERMEL, Noemy; DIAZ, Maravillas. Educación formal y no formal. Un punto de encuentro en educación musical. Aula abierta, v.42, n.1, p. 47-52, 2014. DOI: 10.1016/S0210-2773(14)70008-3

BISQUERRA, Rafael; AIZINA, Rafael. Metodología de la investigación educativa. Madrid: La muralla, 2004, 460p.

BRODSKY, Warren; KESSLER, Yoav; RUBINSTEIN, Bat-Sheva; GINSBORG, Jane; HENIK, Avishai. The mental representation of music notation: Notational audiation. Journal of Experimental Psychology: Human Perception and Performance, v. 34, n.2, p.427-445, 2008. DOI: https:// doi.org/10.1037/0096-1523.34.2.427

CALDERÓN-GARRIDO, Diego, CISNEROS, Pablo; GARCÍA, Isaac; DE LAS HERAS, Rosa. La tecnología digital en la educación musical: una revisión de la literatura científica. Revista Electrónica Complutense De Investigación En Educación Musical - RECIEM, v. 16, p.43-55, 2019. https://doi.org/10.5209/reciem.60768

Calderón-Garrido, Diego; Gustems-Carnicer, Josep; Carrera, Xavier. (2020). La competencia digital docente del profesorado universitario de música: diseño y validación de un instrumento. Aloma. Revista de psicología, ciències de l'educació i de l'esport, v. 38, n.2, p. 139-148, 2020. http://www.revistaaloma.net/index.php/aloma/article/view/425 Calderón-Garrido, Diego; Carrera, Xavier; Gustems-Carnicer, Josep. Music Education Teachers' Knowledge and Use of ICT at Spanish Universities. International Journal of Instruction, v. 14, n.2, p. 831 844. https://www.e-iji.net/dosyalar/iji_2021_2_46.pdf

Crawford, Joseph; Butler-Henderson, Kerryn; Rudolph, Jürgen; Glowatz, Matt; Burton, Rob; Magni, Paola; Lam, Sophia. COVID-19: 20 Countries' 
Digital competence and the use of technological resources by teachers in music... Isaac Diego García Fernández • Juana María Anguita Acero • Rosa de las Heras-Fernández • Diego Calderón-Garrido

Higher Education Intra-Period Digital Pedagogy Responses. Journal of Applied Teaching and Learning, v. 3, n. 1, p. 9-28, 2020. DOI: 10.37074/jalt.2020.3.1.7

CHO, Sunnggi; BAEK, Yoome; CHOE, Eileen. A strategic approach to music listening with a mobile app for high school students. International Journal of Music Education, v. 37, n.1, p.132-141. 2019. DOI: https://doi.org/10.1177/0255761418819016

CHAN, Liz; JONES, Ann; SCANLON, Eileen; JOINER, Richard. The use of ICT to support the development of practical music skills though acquiring keyboard skills: A classroom based study. Computers \& Education, v.46, n.4, p.391-406, 2006. DOI: https://doi.org/10.1016/j. compedu.2004.08.007

Delalande, François. La enseñanza de la música en la era de las nuevas tecnologías. Comunicar, n. 23, p. 17-23, 2004. DOI: https://doi. org/10.3916/C23-2004-04

DWIVEDI, Yogest; HUGHES, Laurie; COOMBS, Crispin. et al. Impact of COVID-19 pandemic on information management research and practice: Transforming education, work and life. International Journal of Information Management, v. 55, n.1002211, 2020. DOI: 10.1016/j. ijinfomgt.2020.102211

Díez-Latorre, Nuria. La formación en TIC de los pedagogos de música. Análisis de la situación actual en las enseñanzas superiores de música. Revista Electrónica de LEEME, n, 42, p. 31-51, 2018. DOI: 10.7203/ LEEME.42.13067

Díez-Latorre, Nuria; Carrea, Xavier. Integración de las TIC en los procesos de enseñanza-aprendizaje de la especialidad de Pedagogía en los conservatorios superiores de música. RIITE. Revista Interuniversitaria de Investigación en Tecnología Educativa, n. 5, p. 40-55, 2018. DOI: http://dx.doi.org/10.6018/riite/2018/342681

FARRIMOND, Barry; GILLARD, D., BOTT, D., AND LONIE, D. Engagement with technology in special educational \& disabled music settings.

Youth Music Report, p. 1-40, 2011. Available at: https://network. youthmusic.org.uk/engagement-technology-special-educationaldisabled-music-settings Accessed on May 1, 2021. 
Digital competence and the use of technological resources by teachers in music... Isaac Diego García Fernández • Juana María Anguita Acero • Rosa de las Heras-Fernández • Diego Calderón-Garrido

FERM Cecilia; JOHANSEN, Geir; JUNTUNEN, Marja-Leena. Music teacher educators' visions of music teacher preparation in Finland, Norway and Sweden. International Journal of Music Education, v. 34, n.1, p. 49-63, 2016. DOI: https://doi.org/10.1177/0255761415584300

GALERA, MAR; TEJADA, JESÚS; TRIGO, EVA. EL EDITOR DE PARTITURAS COMO MEDIO PARA FACILITAR EL ESTUDIO DE LA LECTURA MUSICAL CANTADA. ELECTRONIC JOURNAL OF RESEARCH IN EDUCATIONAL PSYCHOLOGY, N. 29, P. 215-238, 2013.

GARCÍA, Isaac Diego. Reflexiones en torno a la noción de arte sonoro y los límites y contextos del grafismo musical. Arte, Individuo y Sociedad, 32 (1), p- 97-116, 2020. DOI: https://doi.org/10.5209/ ARIS.62464

GIRÁLDEZ, Andrea. (Coord.). De los ordenadores a los dispositivos móviles. Propuestas de creación musical y audiovisual. Barcelona: Graó, 2015, 162p.

Gisbert, Mercè; González, Juan; Esteve, Francesc. Competencia digital y competencia digital docente: una panorámica sobre el estado de la cuestión. RIITE. Revista Interuniversitaria de Investigación en Tecnología Educativa, n. 0, p. 74-83, 2016. DOI: http://dx.doi. org/10.6018/riite/2016/257631

Gorgoretti, Basak. The use of technology in music education in North Cyprus according to student music teachers. South African Journal of Education, v. 1, n. 39, p. 1-10, 2019. DOI: https://doi.org/10.15700/saje. v39n1a1436

Gutiérrez, Alfonso; Palacios, Andrés; Torrego, Luis. La formación de los futuros maestros y la integración de las TIC en la educación: anatomía de un desencuentro. Revista de educación, n. 352, p. 267-293, 2010. Available at: http://www.revistaeducacion.educacion.es/ Accessed on May 1, 2021.

Hagood, Margaret Carmody; Skinner, Emily Neil. Appreciating plurality through conversations among literacy stakeholders. Journal of

Adolescent \& Adult Literacy, v. 1, n. 56, p. 4-6, 2012. Available at: https://ila.onlinelibrary.wiley.com/doi/pdf/10.1002/JAAL.00093 Accessed on May 1, 2021. 
Digital competence and the use of technological resources by teachers in music... Isaac Diego García Fernández • Juana María Anguita Acero • Rosa de las Heras-Fernández • Diego Calderón-Garrido

Ho, Wai-chung. Use of information technology and music learning in the search for quality education. British Journal of Educational Technology, v. 1, n. 35, p. 57-67, 2004. DOI: https://doi.org/10.1111 /j.1467-8535.2004.00368

HUDDY, Avril. Digital technology in the tertiary dance technique studio: expanding student engagement through collaborative and co-creative experiences. Research in Dance Education, v.18, n.2, p.174-189, 2017. DOI: https://doi.org/10.1080/14647893.2017.1330327

Jeffrey, Bob; Craft, Anna. Teaching creatively and teaching for creativity, distinctions and relationships. Journal of Educational Studies, v. 1, n. 30, p. 77-87, 2004.DOI: https://doi.org/10.1080/0305569032000159750 Krumsvik, Rune Johan. Situated learning and teachers' digital competence. Education and Information Technologies, v. 13, n. 13, p. 279-290, 2008. DOI: 10.1007/s10639-008-9069-5

LETAILLEUR, Alain; BISESI, Erica; LEGRAIN, Pierre. Strategies Used by Musicians to Identify Notes' Pitch: Cognitive Bricks and Mental Representations. Frontiers in Psychology, v. 11, p. 1-22. DOI: 10.3389/ fpsyg.2020.01480

López, Rafael. (2011). T.I.C. y entornos virtuales en los Conservatorios de Música: Creación de recursos. Software específico. Temas para la Educación. Revista digital para profesionales de la enseñanza, n. 12, p. 1-14, 2011.

Mark, Michael; Madura, Patrice. Music education in your hands. New York: Routledge, 2010, 176p.

MAÑAS Antonio; ROIG-VILA, Rosabel. Las Tecnologías de la Información y la Comunicación en el ámbito educativo. Un tándem necesario en el contexto de la sociedad actual. Revista Internacional d'Humanitats 45, 75-86, 2019.

NIJS, LUC; LEMAN, Marc. Interactive technologies in the instrumental music classroom: A longitudinal study with the music paint machine. Computers \& Education, n. 73, p. 40-59, 2014. DOI: https://doi. org/10.1016/j.compedu.2013.11.008 
Digital competence and the use of technological resources by teachers in music... Isaac Diego García Fernández • Juana María Anguita Acero • Rosa de las Heras-Fernández • Diego Calderón-Garrido

Ordoñana, José Antonio; Laucirica, Ana; Tejada, Jesús. Estudio cualitativo sobre el uso de programas informáticos para el desarrollo de destrezas rítmicas en la enseñanza musical especializada. Revista de psicodidáctica, n. 17, p. 127-136, 2004. Available at: http://www. ehu.eus/ojs/index.php/psicodidactica/article/view/182/178 Accessed on May 1, 2021.

Palau, Ramón; Usart, Mireia; Ucar, María José. La competencia digital de los docentes de los conservatorios. Estudio de autopercepción en España. Revista Electrónica de LEEME, n. 44, p. 24-4, 2019. DOI: https://doi.org/10.7203/LEEME.44.15709

Palau, Ramón; Mogas, Jordi; Ucar, María José. ¿Cómo han gestionado los conservatorios de música españoles los procesos de enseñanzaaprendizaje durante el confinamiento del COVID-19? Revista Electrónica de LEEME, n. 46, p. 108-124, 2019. DOI: 10.7203/ LEEME.46.18110

PODOLAK, Olivia; Schmuckler, Mark A. Tonal and textural influences on musical sight-reading. Psychological Research, v. 84, p. 1920-1945, 2020. DOI: 10.1007/s00426-019-01187-1

REID, Alison; RAKHILIN, Marina; PATEL, Aniruddh; URRY, Heather; THOMAS, Ayanna. New technology for studying the impact of regular singing and song learning on cognitive function in older adults: A feasibility study. Psychomusicology, v. 27, n.2, p.132-144, 2017. DOI: https://doi.org/10.1037/pmu0000179

RISNER, Doug; ANDERSON, Jon. Digital Dance Literacy: an integrated dance technology curriculum pilot project. Research in Dance Education, v. 9, n.2, p. 113-128, 2008. DOI: https://doi. org/10.1080/14647890802087787

Román-Álvarez, Miguel. Tecnología al servicio de la educación musical. Revista Española de Pedagogía, v. 268, n. 75, p. 481-495, 2017. DOI: https://doi.org/10.22550/REP75-3-2017-09 ROWE, Victoria; TRIANTAFYLLAKI, Angeliki; ANAGNOSTOPOULOU, Xristina. Young pianists exploring improvisation using interactive music technology. International Journal of Music Education, v. 33, n.1, p. 113-130, 2015. DOI: https://doi.org/10.1177/0255761414540137 
Digital competence and the use of technological resources by teachers in music... Isaac Diego García Fernández • Juana María Anguita Acero • Rosa de las Heras-Fernández • Diego Calderón-Garrido

SILVEIRA, Jason; GAVIN, Russell. The effects of audio recording and playback on self-assessment among middle school instrumental music students. Psychology of Music, v. 44, n. 4, p.880-892, 2016. DOI: https://doi.org/10.1177/0305735615596375

Southcott, Jane.; Crawford, Renée. The intersections of curriculum development: Music, ICT and Australian music education. Australasian Journal of Educational Technology, v. 1, n. 27, p. 122-136, 2011. DOI: https://doi.org/10.14742/ajet.987

Stephenson, Jennifer; Limbrick, Lisa. A review of the use of touch-screen mobile devices by people with developmental disabilities. Journal of Autism and Developmental Disorders, v. 12, n. 45, p. 3777-3791, 2015. DOI: https://link.springer.com/ article/10.1007\%2Fs10803-013-1878-8

Webster, Peter. Computer-based technology and music teaching and learning: 2000-2005. In: Bresler, L. (Ed.). The new handbook of research on music teaching and learning. New York: MENC / Oxford University Press, 2007, p. 1311-1328.

Webster, Peter. Historical perspectives on technology and music. Music Educators Journal, v. 1, n. 89, p. 38-43, 2002. DOI: https://doi. org/10.2307/3399883

WÖLLNER, Clemens; HALFPENNY, Emma; HO, Stella; KUROSAWA, Kaori. The effects of distracted inner hearing on sightreading. Psychology of Music, v. 10, n.31, p. 377-389, 2003. DOI: https://doi. org/10.1177/03057356030314003

\section{Financiamento}

The current investigation is part of the "Conocimiento y uso de la tecnología educativa en maestros y profesores de música" [Knowledge and use of educational technology of Music teachers and professors] competitive project (ID B0036), funded by the International University of La Rioja. 
Digital competence and the use of technological resources by teachers in music... Isaac Diego García Fernández - Juana María Anguita Acero • Rosa de las Heras-Fernández • Diego Calderón-Garrido

\section{Publisher}

Universidade Federal de Goiás. Escola de Música e Artes Cênicas. Programa de Pós-graduação em Música. Publicação no Portal de Periódicos UFG.

As ideias expressadas neste artigo são de responsabilidade de seus autores, não representando, necessariamente, a opinião dos editores ou da universidade. 